\title{
Negotiating Faith and Culture: De- Orientalising hegemonic representations of the ancient city of Banaras
}

\author{
Maya Vinai ${ }^{1} \&$ Vinai Sankunni ${ }^{2}$ \\ ${ }^{1}$ Assistant Professor, Dept of Humanities and Social Sciences, BITS-Pilani (Hyderabad \\ Campus).ORCID: orcid.org/oooo-ooo1-5217-9645. Email: mayavinai@hyderabad.bits- \\ pilani.ac.in \\ ${ }^{2}$ Director, Support - Global Delivery Center, WPP Group of Companies, Kantar Operations
}

Received July 30, 2017; Revised September 05, 2017; Accepted September 15, 2017; Published September 20, 2017.

\begin{abstract}
Banaras has forever remained an enchanting place since millennia. If the colonial era pinned down, Banaras as an exotic site for theology and spirituality; the post-colonial era has witnessed the de-mystification process of legends and beliefs associated with Banaras. However, every time Banaras is bracketed, a new facet emerges. This paper presents two contesting visions of Banaras and also the argument that; there can be no absolute version of truth because such deliberations not just posit a conflict within the national imagination but also creates falsifications across borders. The universalized and monolithic understandings offered on Banaras from the elite metropolitan locations and through media have paved way for creation of certain stereotypes regarding Banaras in the public imagination. This in turn, has led to a shelving and obstruction to the multiple realities and unaccounted stories on Banaras. In this paper, to understand the hidden nuances of the cityscape of Banaras we have looked at Pankaj Mishra's popular novel The Romantics along with a local boatman's perspectives on aspects like choice of profession, their historic contribution to the city, presence of electric crematoriums, various development policies introduced by the government, and regular conflicts with the hegemonic groups to possess the ritual space.
\end{abstract}

Key words: Banaras, representation, hegemony, alternate narratives, counter establishment, boatmen, legends, modernity.

The word Banaras, means "Nectar of life". On various occasions, writers and poets have written eloquently about the city which in-turn has become the identity of the place and the nation. The city has captured the fancy of the believers and skeptics, historians and hippies, travelers, artists and mystics. Banaras, the ancient city has been the most preferred cultural and religious hub of Indians. There are accounts of the city's significance since ancient times: the historiography of the place which has been documented spans or ranges from integration of Vedic tradition in the Gangetic valley, to witnessing of Buddha's teachings on the banks, to wanderings of revered Jain monks for alms, construction, expansion and consecration of its several ghats and temples during the earlier centuries. Its global significance increased manifold with the British stamping it as 'holy city of Hindus.' There are two factors which distinctly demarcates Banaras from its sister pilgrimage sites. First, Banaras was centrally situated astride the Ganges and at the hub of an ancient sub-continental road network, within reach of western, central, and eastern India. More importantly, Banaras was perceived as the center of the world, the place of creation, the holiest

(C) AesthetixMS 2016. This Open Access article is published under a Creative Commons Attribution Non-Commercial 4.0 International License (http://creativecommons.org/licenses/by-nc/4.0/), which permits non-commercial re-use, distribution, and reproduction in any medium, provided the original work is properly cited. For citation use the DOI. For commercial re-use, please contact editor@rupkatha.com. 
spot on earth, and the ultimate destination for all Hindus. Endowed with such authoritative religious sanction, it easily surpassed other centers in importance. (Freitag 232)

This city which been lauded as the holy city has a history dating back to 4000 years and has been of great interest to not only the rulers, historians, anthropologists, spiritual seekers but also to literary artists. Noted regional writers like Premchand (Bazar-e-Husn), Samaresh Basu (Ganga), M.T Vasudevan Nair (Varanasi), Bibhutibhushan Bandopadhyay (Pather Panchali) have explored the socio-cultural dimensions of Banaras. Indian English writers like Pankaj Mishra, Chetan Bhagat, Ashok Srinivasan have used Banaras as the backdrop to set their novels. Of late, its popularity has re-emerged as it has become one of the most sought-out setting for television serials aired on national channels.

As a city, Banaras captivated the foreign attention both from inside and outside the academic world. From colonial descriptions of the city, portraying it as a 'living museum', to the more recent studies which have examined Banaras as a paradigmatic pilgrimage centre (Eck 1983), the city remains one the most sought-out destinations in India for anthropologists too. Several anthropological studies have been centered around Banaras. Assa Doron, ARC Future Fellow in Anthropology and director of the South Asian Research Institute at the Australian National University lists out a few areas worked upon by leading researchers: craftsmanship (Kumar 1988; Raman 2010), the death industry and what constitutes a 'good death' in the holy city(Parry 1994; Justice 1997), issues of environmental, moral, and physical degradation (Cohen 1997), masculinity (expressed through wrestling) and womanhood, examined through the prism of ritual practices (Alter 1992; Pintchman 2005)

Often people tend to surreptitiously believe what is easily available to them and form perceptions on the basis of evidence shown in the form of images, narratives and statistics shown. Standardizations of people, processes and culture have over-simplified an individual's task of sorting out their preferences and alignment; without having put too much of critical insight and efforts. In a world driven by consumer culture and constantly popping deadlines, we are becoming easy pawns to market politics conceived by researchers, who try to universalize processes and standardize cultures. Hegemony is allowing perceptions of one dominant group to be decried as 'that which relates to reason' and canonical and to become embedded in the culture. This invariably would lead to a negation or erasure of the multitude of voices spurting from the margins which might have an alternate visualization of the same phenomenon.

To understand Banaras, we need to contextualize not just the cityscape (and the hegemonic voices from West, scholarly discourses or deliberations by creative writers) but also carefully re-look at lives of the inhabitants of Banaras (who have settled there for ages). Viewing the world through an alternate lens, changes one's experience of perceiving things around. It provides the readers fresh insights on the existing concepts, paradigms, and offers better conflict resolution choices. In fact it is these oral narratives, folklores and beliefs of marginalized sections like the boatmen, the doms, weavers (of Banarasi sarees) aids in keeping up the sanctity, uniqueness and beauty of Banaras alive by passing on the fables of collective myth down to pilgrims and tourists.

In this paper we put forth two contesting visions or representations- the first one is that of the metropolitan writer Pankaj Mishra who writes from an elite location, thereby representing Banaras to a global audience. We have taken the novel The Romantics due to the uniqueness of the writer's location and his access and capability to mould the perceptions of a worldwide audience. The second narrative which we concurrently focus and which provided us a rare peek hole to reflect and perceive Banaras is that of a boatman whom we came across during one of our 
trips to the ghats. This boatman belonged to the Nishada / Mallah tribe and was engaged in showing the various facets of Banaras to both- the believers and non-believers.

The boatmen of Banaras have historically been a marginalized community. They are subalterns in the sense that they have limited access to modern institutions like education; public service and political representation (Doron 19) The British categorized and relegated these tribes under the criminal caste category. The idea of re-presenting Banaras from below would provide an impetus to re-examine 'the inadequacy of elitist historiography' (Guha 2) The boatmen's oral narrative of transmitting culture and history to the exodus of spiritual seekers and travelers fulfills the function of embedding certain forms of knowledge which comes from their own lived experience and folk traditions passed down by their ancestors. However, it is surprising to note that a boatman's perspective which is central to the physical and social construction of Banaras, in terms of its trade, pilgrimage and tourist economy has hardly been attempted except for a very few anthropologists. This paper examines the reproduction of Banaras as a sacred place in fictional narratives of Mishra and the contesting visions provided in oral narratives of boatmen.

The argument I wish to forward through this paper is that the representations of the city of Banaras is a cultural negotiation and is nevertheless highly dependent on both the location and vocation of the person representing the same. The areas which I would focus can be broadly classified as: a) The physical representation of Banaras b) Depiction of the indigenous natives of Banaras c) Attitude towards changes happening in Banaras

\section{Mishra's re-creation of Banaras and its indigenous natives}

Mishra's worldview of Banaras is shared by a huge global audience and perhaps many amongst them are oblivious of the cultural significance of Banaras. His location in this essentializing project of fabrication of the city of Banaras is that of an upper caste metropolitan writer's negotiation of Banaras within an Anglicized frame. The Banaras he unfolds is chaotic, unpredictable, sensual (with hues of colours and smells) and mystifying. Through the protagonist Samar, a young man of limited means, who moves to Banaras for pursuing his education, Mishra focuses on images like: "narrow alleys", "rubbish in uneven mounds", "neglected statues of important leaders", "road full of potholes", "unseasonal downpours", traffic jams, bulging autorickshaws and hub for alternative medicine and so on. His construction of Banaras is further strewn with Naga-sadhus, drug peddlers, casteism and ruthless college politics. In addition to this, Mishra's narrative is peppered with myths taken from Hindu scriptures concerning Banaras that to die in Banaras is to redeem oneself from the cycle of birth and deaths. These visual images resonates the viewpoint furnished by Mark Tully in his book India's Unending Journey (2007) of how Varanasi or Banaras is the only city in the world where crematoriums on the ghats have become places of tourist attraction. A quick reading of the narrative is enough bring to the reader's attention; the reinforcement of the certain Oriental perceptions and stock images passed down the generations. The presence, embedding and reproduction of these images in a postcolonial novel set in $21^{\text {st }} \mathrm{C}$ casts a skeptical gloom on whether the fictional writers have really moved ahead with representations or whether they too, at certain junctures enliven the Orientalist documentation of the colonial natives in a prosaic manner.

Miss West's attitude towards the end reflects the resurfacing of these imperialistic tendencies. Anand's break up from his French girlfriend Catherine and the consequent return from Paris to Delhi is explained to Samar in the following manner: 
His love for Catherine, his time in Paris: this was the greatest thing that could happen to him. He had only this past and he was trapped by it. Catherine could move on, but he was stuck. She is drifting, too, poor girl, but she is supported by her father's money, her culture, her background; they give her at least an idea of what she owes to herself. Anand, people like him, they can't afford such ideas; they don't know who they are; they don't know what they want; they are just trying hard not to sink into the misery and wretchedness they are born into. That's what he is doing now. (273)

Thus Miss West succeeds in building up the image of an Orient as a negation of the West, i.e the other side of rationality, science, development, prosperity and so forth. The indigenous natives are perceived as fraught with inconsistencies and complacence. Shyam, Mrs. Pandey's assistant with his stock dialogue "Greed...is the biggest evil. It destroys families, sunders sons from parents, husband from wife...." (11) can be seen as the best example of an effeminate Oriental character. The background or chores he is set against is scrubbing of brass dishes, staring at guests, slowly chewing tobacco, fanning the chulla fire... He lived a neutered life of a feudal retainer and is particularly not aware of anything apart from his mistress's wishes. Edward Said in his book Orientalism (1995) argues that alongside their military triumphs and economic conquests of the Orient, the Europeans created an entire body of knowledge which enabled them to represent the Orient, such representations, moreover, far from having any necessary relationship to the Orient, reveal more about the 'natives' and their cultural practices, social institution and the like. Such representations slot the natives into the cartel of lazy, unenterprising and relegate them to a subordinate status. Several travel books expound these presumptions. For example one of the best known travel guide written by W.S Caine called The Picturesque India: A handbook for European Travelers (1898) reiterate on the same idea as how the local professional guides are incompetent to show a true picture of the city and how the guides belonging the colonial Clarke's hotel can make the necessary arrangements. The only aspects of concern for the local guides are tips and commission beyond which they hardly think anything about. (202-203)

Similarly the boatman Ramchand, is construed as both erotic and exotic by the western fantasy. Miss West's attitude to Ramchand reflects on the perennial western gaze on the Orient as an object of desire.

Miss West had her own favourite boatman: his name was Ramchand and he came running up the steps as soon as she and I appeared on the ghats that evening. He was a strikingly handsome man with beautifully sculpted muscles on his lean, chocolate-brown body, most of which was bare, his only item of clothing being a dhoti, which he wore like a gstring, tightly around his hips and buttocks. He held his palms together before Miss. West; bowed his head; he looked eager to serve (113)

In addition, Mishra's Banaras becomes a site for acquisition of the so-called 'deviant knowledge, which is incomprehensible and beyond the logic of the Western mind. Mark who comes to India to study alternative medicine stands as a radical opponent of the concept of received knowledge bestowed by Western societies. Mark's acceptance of the indigenous form of knowledge is rare of its kind and a defining moment. Although momentary, it can be interpreted as a counter attack on the dominance of Western pedagogy and institutionalized knowledge systems which increasingly de-centralize knowledge and power coming from the colonial states. Ashish Nandy in his book Talking India (2012) conceptualizes this question as to why it is that plurality is admitted in some spheres of life, but not permitted in other domains. He argues that the 'Enlightenment vision and secular ideologies allow one to pluralize the domains of spirituality and religion', but that a 'plurality of knowledge, particularly that of science, is seen as dangerous, 
subversive, and a challenge to the intellectual and moral status of the most deeply entrenched elites of our times.' (58)

\section{Depiction of change/modernity in Banaras in Mishra's narratives.}

Mishra's Banaras hasn't undergone much of a change and is nevertheless static and it continues to harness its reputation for 'slow leisurely life of Old Banaras.' (276) Except for a few changes like modern gadgets introduced into the markets, change in the consumption pattern of the middleclass and their materialistic desires, Mishra's Banaras reinforces the colonial view of a certain India which has remain stuck in antiquity. It resonated the acceptance of textual view of the society in antiquity by Orientalist and also led to a picture of Indian society as being static, timeless and spaceless. (Bernard .S. Cohn qtd from Vinay Lal, 2)

However there has been a marked change in the raison d'être why people from the West come to Banaras. Although Occident's motive in collecting facts about the Orient was one of the discursive ways to harness power and control, the character of Mark in The Romantics symbolizes a paradigmatic shift in such an attitude. His experience of Banaras foregrounds new avenues for humanistic projects which could help in improving and helping to connect individuals. He says to Miss West:

You know, one of the great things about me coming to India has been knowing about poverty and pain and suffering and realizing that there's a whole world outside America where people don't even have the basic things in life. I mean, you keep seeing all those things in television, you know, those starving kids in Africa, but somehow you never get close enough to really feel it. It doesn't register much. Its just out there on a map and you never really care as much as you should. And when you see it face to face and, boy, it knocks you out. I feel I have been lucky in this respect both as an artist and a human being. Not many people get the chance to experience all this. Back home, we are kind of trying to forget what pain and suffering are.... ...this machismo...makes...pathetic failures. I mean spiritually, because we don't allow ourself to suffer, experience pain. What I want to do when I get back is find a way of sharing my experience of Banaras and find some way of integrating it into daily life. (15)

The 6o's and the 70's was a period of counter-culture whereby Westerners tried to experience new things through travelling to so-called exotic lands, through spirituality, drugs, music, food and their interactions with indigenous locals. Julie Stephens argues that India signified freedom and an opportunity to "counter all restrictions of "Western" culture....(it) came to be seen as an uncontaminated place, far from the polluting influences of money; a place beyond the market where the ethic of "free" could flourish supreme' (Stephens 1998, 53) The counter culture celebrated the lack of material modernity as a sign of spirituality, concerned, as counter-culture was, with renouncing the acquisitiveness and accumulation of material possessions and achieving a harmony with nature. Thus such perceptions of India as a place of discovery (and self-discovery) and spirituality continue to inform travel discourses and patterns of consumption.

Mishra vehemently brings out the anarchy behind BHU, the Oxford of East. Behind the impressive façades of old buildings and towers he gradually brings in the disarrayed academic sessions, teacher-student politics, shooting on streets, violence by students with country-made revolvers. He shows how the hostels were not inhabited by students but were mostly sought after by the outsiders who used to wait for their miracle government jobs in these rooms as the rents 
were very low. The author while forwarding Banaras as pre-dominantly Hindu pilgrimage center and site for campus and communal politics; conveniently sidelines or ignores Banaras as a place which also has a history of strong Buddhist culture, Islamic architecture and stories from margins like that of weavers of Banarasi sarees, boatmen. Doms etc.

Another perspective of Banaras was framed during one of our trips to Banaras last December. With a motive of discerning the palimpsest layers of complexity and mysticity which enveloped the city of Banaras, we met various sadhus, priests, pilgrims, auto-drivers, road-side chai-wallas, monks and the dom's (people who traditionally are the caretakers of the cremation grounds). Amidst all the perspectives provided by mystics and the local auto-wallas; we fortunately came across a boatman cum guide who ferried us through the various ghats. The boatmen of Banaras are negotiators of culture; they fabricate the mysticity of Banaras to both the tourists and pilgrims alike. The narration of the multi-faceted Banaras came simultaneously as a surprise and shock. All experiences and timeless historicity of Banaras the boatman shared with us were recounted and intercepted whilst passing the smooth trail down the holy Ganga to view the Manikarnika ghat (where funeral rites are conducted round the clock) which antagonistically reflected on the impermanence of life. Today, many of us happily reside in smart cities and try to contrive the realities around us through the images repeatedly flashed by visuals and news clippings provided by Rupert Murdoch's and Mark Zuckerberg's empire, which awakens just our visual and auditory senses. But here the boatman's story set and narrated in the backdrop of these ghats and mesmerizing Ganga Aarti or the ceremonial worship of River Ganga performed during the dusk enriched and reawakened all the four senses- namely olfactory (by feeling the warmth and glow of fire reflected from lamps on the ghats), auditory (by listening to chanting of mantras), visual (seeing the rites and rituals) and nasal (smells emanating from agarbattis and dhoops).

Boatmen who belong to the Mallah/Nishada tribe have historically been a marginalized community. They are subalterns in the sense that they have limited access to modern institutions, including education, public services and political representation. According to Assa Doron, ARC Future Fellow in Anthropology and director of the South Asian Research Institute at the Australian National University: "They experience domination not only under postcolonial state power, but also under traditional authority and ideological system of caste. In other words, boatmen are disadvantaged in both modern and traditional terms." (19) I have explained this in the later half of the paper. Thus, to be a boatman in Banaras means to be constantly engaged in the contestations over resources, tourists, right to conduct rituals or to ply one's boat in certain spaces along the riverfront.

The boatman's narrative includes or left space for alternate historiographies and also allowed the scope for reiterating from the popular pictorial and textual representation of the city as possessing an exclusively Hindu character. It included Mughal invasions of rulers like Mohammed of Ghazni in the $11^{\text {th }} \mathrm{C}$. His narrative doesn't negate the presence of GyanVyapi and Alamgiri Mosques which stands corresponding to the famous Kashi Vishwanath and BinduMadhav Temple. The Gyan Vyapi temple's construction is dedicated to the Mughal emperor Aurangzeb, who was also responsible for the destruction of the older Kashi Vishhwanath temple. The city of Banaras is also known as Kashi in many of the scriptures, and within the Hindu religious tradition. The other great Muslim shrine which was mentioned by the boatman was the Alamgiri Mosque which is now a "protected monument" under the Archeological Survey of India (ASI) 
The boatman also focused on how building a ghat on the banks of holy Ganges became one of the ways to establish superiority in the region. The principal patrons of the city's rebuilding project was undertaken by the Maratha empire. 'They built many ghats, sponsored religious and educational institutions and began to resettle Brahmins from the Maratha country these. (Desai 25) The boatman accounts also encompassed the impact of colonial invasions on Banaras whereby mammoth attempts were made by the colonizers to modernize the indigenous cityscape and trade routes.

The struggle of the natives to ward off the colonizing attempts is still looked upon with great pride and reverence by the boatman and he further claims that the credit of preserving an uncorrupted Banaras equally goes to their ancestors. For example, the colonizers, in order to reduce thefts in riverfronts and facilitate better transport wanted to introduce mechanized boats to ply in the Ganges. The colonizers had fear of robberies committed by thugs and lower castes on the rivers. It is evident from many writings during this period. Boats were the primary targets for such crimes. Thus boatmen were both a primary threat and necessity to the British interests. After several attempts exasperated Lieutenant Thomas Bacon $(1837,233)$ from the Bengal Horse Artillery noted:

It is utterly impossible to induce the natives to build their boats after any improved system. Year after Year, though they have beautiful European models before their eyes, the obstinate fools persist to turn out hundreds of these execrably devised boats...and why? Because their fathers and their grandfathers before them, and their grandfathers before them, from time immemorial, have continued to build their boats so. (qtd from Doron 27)

And why were these boatmen stuck up with these wooden boats? The main reason for this lies in the deep-rooted reverence for the rites and rituals associated with the process of making boats and the inherent fear that any deviation from the said process (selecting the specific kind of wood for making the boat, conducting auspicious rites at the beginning and after completion of the whole process, assigning work to a particular group of people) would lead a calamity inhibited their preference for mechanized boats.

It also draws attention to the fact as to how every successful model in the Western context may not be viable or feasible in a Indian context. Such accounts of resistance against the colonial powers remain an unchartered domain in the fictional narratives. In other words, the boatman bestows credit to their forefathers and believes that it is their united aggression and pride in the continuing their legacies that has kept the Banaras charm alive for centuries.

The discourse of modernity in terms of cleanliness in fictional narratives that surrounds the cityscape of Banaras collides with the boatman's perspective of hygiene and cleanliness. Although over the couple of decades Banaras has undergone a lot of changes, the boatman's attitude to the modernity projects remain the same. They are skeptical and indifferent to most of the projects introduced by the state machinery. The most prominent reform attempted in the last few years is that of Ganga Action Plan (GAP), a waste-management scheme designed by the central Government to clean the polluted river. The GAP is symbolic of the Indian government's commitment to protecting the environment by utilizing modern means, as well as demonstrating national concern for the health of its people. GAP was the adoption of a western model developed by the Thames water authorities to clean the river. In a blind attempt to imitate the Western model the authorities forgot to check its feasibility in India which became ineffective due to frequent power cuts that happen in Banaras thereby leading the sewage to once again flow back to the river. 
The boatman's perspectives to these government schemes were quite apprehensive and he believed that it was unsuccessful as it didn't involve the consent of the local natives. Policies like ban on fishing, eradication of sand mining from the eastern side of the river were more of a hassle for the locals as these restrictions almost brought them to the brink of starvation. On the contrary, many boatmen feel that it not the remains of the deceased which lead to pollution of Ganga it is the continual dumping of industrial and urban sewage which makes Ganga polluted. According to the boatman "Mother Ganga can be cleansed only by herself and no one else." In Banaras, people use the River Ganga and other water bodies such as local wells and ponds, as convenient places for disposing of unwanted items, such as guns, tax books, and stolen goods. Animal carcasses and human corpses are also sometimes thrown into the river to avoid costly cremations, as it is considered both a convenient and auspicious alternative. (Doron 64)

The water from Ganga popularly referred to as Ganga Jal plays an integral role in ritual practices for residents and pilgrims. Ablution in the early morning hours is a component of daily ritual for pilgrims and some residents. Residents and pilgrims immerse the ashes or bones of the cremated into Ganga to ensure their safe journey to the realm of the ancestors. Uses of Ganga Jal for puja (offerings to deities) affirm the eternal essence of the river. Pilgrims and residents take drops of Ganga Jal in the mouth as a gesture of nourishment. These ritual uses of Ganga Jal are distinguished from her secular purposes to provide for potable needs through the city's water system. (Alley 127-145) From almost July-Sep, the entire ghat region of Ganga is submerged in water; washing away all the impurities and residues. In fact, the boatman claims that the reaction of his community is not very affirmative to many of these reformations and Government interventions. They have started their own campaigns to clean Mother Ganga.

Many awareness drives by spiritual leaders, politicians, film stars have added on to the pressure amongst the locals to keep their cityscape clean and sacred. Recently members of the boatmen fraternity have become increasingly aware of the need to reduce the pollution levels. The Press release by All Embracing National Nishad Awareness Assembly (Ranshtriya Nishad Jagran Mahasabha) shows:

In this first phase of this campaign to clean the river, the community joined hands and raised their voices calling slogans, like: Ma Ganga Ki Seva Mallah karega (Mallahs will perform the service for Mother Ganga), Ganga Seva, Bharat Seva (Service to Ganga is service to the Nation)...Nishaad Ektaa Zindabad ...In addition, members of the community used their boats and motorboats to collect rubbish from the river... Concluding the programme in Dashashvamedh ghat, a senior member of the community said: "Whoever cleans Ganga Ma clearly deserves to be called Gangaputra..' (qtd from Doron 86)

\section{Introduction of Electrical Crematoriums}

The two mesmerizing ghats on the banks of Ganga is the Harishchandra ghat and Manikarnika ghat. It is on these two ghats that the physical body of the deceased gets a farewell along with the rites and rituals. These ghats present a conflicting picture of tradition and modernity in terms of the disposal of physical body. Harishchandra ghat has provision for traditional cremation as well as modernized electrical crematoriums. Western electrical crematorium was introduced in Banaras in January 1989 as a part of the GAP as it was more environmental friendly and cost effective. The cost of electric crematoriums is less than the traditional one, the cost of electric crematorium is rupees five hundred whereas the traditional crematorium would cost at least four thousand to five thousand rupees. Further if the former took forty five minutes the later would at 
least take four to five hours to finish the process. Furthermore it was built to meet the growing requirement of people who would come to Ganga to perform these rites during the months of monsoon from July to September when the burning of these pyres would become very difficult due to heavy rains. Any negligence on the part could lead to a break of epidemic.

But inspite acknowledging all these positive attributes, the preference of the boatman's and his fraternity is tilted towards the traditional cremation. Apart from this forming the main livelihood for several natives, the boatman has two grounds on which he justifies his preference for a traditional crematorium thereby blocking all the agents of change ushering into this sacred space. The first one he explains is that the entire process of performing rites and rituals near the riverfront has a very cathartic and recuperative effect on the person who has undergone a deep sense of loss. The individual's recovery to the normal self is accelerated as they undergo this process of rites and rituals. The second one is more religiously rooted that once the human being leaves his/her physical body, he/she will transcend to the next janma (birth) or attain moksha (salvation) when these rituals are performed with reverence. Thus many of the modernity projects ushered in find very little scope to make alterations in this ancient city as it lacks support from the local indigenous crowd which is still very deeply rooted in the traditional beliefs.

\section{Choice of Alternate Occupations}

In the Vedic ages, Varna was detrimental in making the choice of occupation. The fluidity to transcend occupation vanished after the Vedic age. And there was a heavy pressure on the individuals to rely on the family occupations continued as a lineage. Attempts to modernize themselves and the colossal force of social reforms in the $19^{\text {th }}$ and $20^{\text {th }} \mathrm{C}$ motivated many people to seek out alternate avenues of employment and shun the professions that was designated 'lowly' and 'polluting.' Paradoxically, inspite of belonging to the Nishada/Mallah community these boatmen were never really outcaste or were not as stigmatized as their services were of paramount importance and had the access to conduct certain rituals even for the hegemonic upper castes. They were privileged to conduct certain pujas and this developed a strong sense of pride and attachment to their profession.

With the onset of the post-colonial era, the easy availability of skill-based employment, accessibility to education and positive discriminatory policies enforced by the state-government many of the youngsters from the boatman's community moved out of their parampara (roughly translated as family tradition) to join the mainstream and enjoy the benefits of a white-collared jobs. But a considerable number stuck to their ancestral profession. Puzzled by this unique convention, we asked the boatman the reason behind this choice. His immediate retort was: "I was destined to do this, as this is my karma." The boatman confidently gave us the reasons behind this conscious choice: a) to carry forward the community-based-occupation very strongly etched in the consciousness of the family b) by donning the mantle of a boatman and sacrificing his own self-interests in favour of the familial interest he is honouring the wishes and tradition of his elders and this karma of his would beget the blessings of both his ancestors and Gods. c) A fear that a break in the lineage-based profession can incur the wrath of the family deity leading to personal and material loss. 


\section{Competing for ritual space: Deconstructing Banaras as an exclusive site for spirituality}

The boatman contests the representation of Banaras as a "site of unalloyed Hindu spirituality." (Desai 28) whereby during his act of ferrying the passengers he cautions them against the crookedness of the priests who get into all sorts of tricks to both woo money from the gullible passengers if they are not alert. The boatmen unconsciously brings forth the unholy nexus between the priests, flower-sellers, boatmen, sellers of pooja items and tourist guides. The tourists or seeker who comes to get an experience of spirituality gets mashed up in the crass materialism expounded by the local custodians of culture in this ancient city.

The boatmen and the religious priests of Banaras have always been in conflict with each other for their rights to conduct rituals in and on the Ghats and riverfront. The boatmen deal with minor deities and officiate rituals that serve the practical needs of the local population with respect to marriage and other domestic concerns like birth and child-rearing, illness and economic livelihood. They do not perform higher priestly functions. The Ganga river is considered as an all-compassing mother, provider, and sustainer becomes a symbol of national unity. She is prayed and paid respect by people from across the country to gain prosperity and welfare. Several rites are conducted by the priests and boatman to symbolize this. It is the lure for 'dakshina' or donation made towards the services of a priest or boatmen after performing these rites that becomes a source of conflict between them. Each group collides with the other when they cross or transgress each other's marked territories and Ghats. Thus many of the optimistic images issued by the Tourism department which hail the unique spiritual experience of Banaras conveniently ignore the scampering for material prosperity amongst the natives.

A careful introspection of all the elitist narratives and historiographies would provide us a framework to counter the universalizing attempts and reveal the fallacies in interiorizing such representations. A concerned lending of our minds and ears to alternate oral histories, myths, and accounts of ritual practices can help us to negate the all-compassing and exclusive nature of Hindu identity of Banaras projected to us and help in comprehending the heterogeneity of the cityscape. It also draws attention to the fact that literary representations need to re-orient their representational strategies to incorporate the changes and challenges of contemporary times in the realm of creative narrative.

\section{Acknowledgement}

I am extremely grateful to P.V.L Narasimha Rao for all the technical assistance provided to me and also to BITS-Pilani (Hyderabad Campus) Library for procuring books for my research work.

\section{References}

Alley, K.D. 1994. Ganga and Gandagi: Interpretations of Pollution and waste in Banaras. Ethnology 33(2): 127-145.

Alter, J. (1992).The Wrestler's Body: Identity and Ideology in North India. Berkeley: University of California Press.

Anderson, B. (1991). Imagined Communities: Reflections on the Origin and Spread of Nationalism. London: Verso.

Caine, W.S. (1898). Picturesque India: A Handbook for European Travelers. Delhi: Neeraj Publishing House. 
Chatterjee, Partha. (1994) The Nation and its Fragments: Colonial and Postcolonial Histories. Delhi: Princeton University Press.

Cohn, Benard. S. Notes on the History of the Study of Indian Society and Culture" in Structure and Changein Indian Society. Eds.Milton Singer and Bernard. S. Cohn (Chicago: Aldine Press, 1968) reprinted in Benard S. Cohn. An Anthropologist among the Historians and Other Essays. Delhi: OUP, 1988, pg 143.

Doron, Assa. (2013). Life on the Ganga: Boatmen and the ritual economy of Banaras. New Delhi: CUP.

Desai, Madhuri. (2003). Mosques, Temples, and Orientalists: Hegemonic Imaginations in Banaras. TDSR. .15. 23-37.

Eck, D. (1983). Banaras: City of Light. London: Routledge and Kegan Paul.

Foucault, Michel. (1997). Discipline and Punishment: The Birth of the Prison. London: Penguin.

Freitag, Sandria B. (1989). Culture and Power in Banaras: Community, Performance, and Environment, 1800-1980. Berkeley: University of California Press.

Guha, R. (1982). 'On Some Aspects of Historiography of Colonial India'. In Subaltern Studies I: Writing on South Asian History and Society, edited by R. Guha, 1-8. Delhi: OUP.

Gol. (1999). A Pilgrimage to Kashi- Banaras, Varanasi, Kashi: History, Mythology and Culture of the strangest and most fascinating City of the World. Varanasi: Indica Books.

Jaqntzen, Grace. (1995). The Philosophy of Christianity. Cambridge: CUP.

Justice, C. (1997). Dying and the Good Death: The Pilgrimage to die in India's Holy city. New York: SUNY Press.

Kumar, S.(1999). Date Line Varanasi. Varanasi: Kashi Patrakar Sangh,

Mishra, Pankaj. (2013). The Romantics. New Delhi: Penguin.

Nandy, Ashish. (2012). Talking India. New Delhi: OUP.

Parry, J. (1994). Death in Banaras. Cambridge: Cambridge UP.

Pintchman, T. (2005).Guests at God's Wedding: Celebrating Kartik among Women of Banaras. New York: SUNY Press.

Raman, V. (2010). The Warp and the Waft: Community and Gender Identity among Banaras Weavers. New Delhi: Routledge.

Said, Edward. (1995). Orientalism: Western Conceptions of the Orient. London: Penguin.

Sarkar, Sumit. (1997).“The Decline of the subalterns” Writing Social History. Delhi: OUP.

Singh K.S. (1998). People of India. Delhi: OUP.

Stephens, J. (1998) Anti- Disciplinary Protest: Sixties Radicalism and Postmodernism. Cambridge: Cambridge University Press.

Tully, Mark. (2007) India’s Unending Journey: Finding Balance in a time of Change. Rider: London. 